\title{
Identifikasi Salmonella sp. Pada Cacing Sutra (Tubifex sp.) Tangkapan Dari Alam dan Hasil Budidaya
}

\section{Identification of Salmonella sp. on Silk Worms (Tubifex sp.) Catch from Natural and Cultural Results}

\author{
Umidayati $^{1}$, Sinung Rahardjo ${ }^{2}$, Ilham $^{2}$ dan Mugi Mulyono ${ }^{2 *}$ \\ ${ }^{1}$ Laboratorium Basah, Sekolah Tinggi Perikanan Jakarta, Jl. Aup Bar. Jl. Raya Pasar Minggu, Jati \\ Padang, Jakarta 12520, Indonesia \\ ${ }^{2}$ Program Studi Teknologi Akuakultur, Sekolah Tinggi Perikanan Jakarta, Jl. Aup Bar. Jl. Raya Pasar \\ Minggu, Jati Padang, Jakarta 12520, Indonesia
}

*Correspondence :

mugi.mulyono@kkp.go.id

Received : 2019-11-15

Accepted : 2020-01-09

Kata Kunci :

Cacing Sutera, Tangkapan alam, Budidaya, Salmonella sp.

Keywords :

Silk Worms, Natural catches, Aquaculture, Salmonella sp.

\begin{abstract}
Abstrak
Cacing sutra merupakan pakan alami yang sangat dibutuhkan pada pembenihan ikan air tawar namun ketersediaannya tidak kontinu dikarenakan kondisi alam yang terbawa arus pada musim hujan. Keberadaan cacing sutra di alam juga dipengaruhi oleh banyaknya bahan organik yang melimpah dari limbah rumah tangga yang cenderung terkontaminasi bakteri yang terdapat pada cacing sutra tangkapan dari alam. Untuk memenuhi kebutuhan kontinuitas cacing sutra dibudidayakan dengan media yang sering adalah kotoran ayam. Untuk penyediaan pakan alami larva ikan sebaiknya diidentifikasi bakteri pada cacing tangkapan dari alam dan hasil budidaya. Penelitian dilakukan di Laboratorium Basah Sekolah Tinggi Perikanan Jakarta pada bulan Mei - Juli 2019 dengan tujuan mengidentifikasi bakteri Salmonella sp. pada media kotoran ayam dan cacing hasil tangkapan alam dan hasil budidaya. Metode identifikasi digunakan untuk penelitian ini dan hasilnya dianalisis secara deskriptif. Hasil penelitian menunjukkan pada cacing sutra dari alam positif mengandung Salmonella sp., sedangkan hasil budidaya negatif tidak mengandung Salmonella sp.
\end{abstract}

\begin{abstract}
Silkworm is a natural feed that is needed in a freshwater fish hatchery. Still, its availability is not continuous due to natural conditions that are carried by the currents in the rainy season. The presence of silkworms in nature is also influenced by the amount of organic material that fills from household waste, which tends to be contaminated with bacteria. To meet the continuous needs of silkworms cultivated with media that often is chicken manure. For the provision of natural food, fish larvae should be identified by bacteria in catching worms from nature and cultivation. The study was conducted at the Wet Laboratory of the State College of Fisheries Jakarta in May July 2019 to identify the Salmonella sp. in the media of
\end{abstract}


chicken manure and worms, which are natural catch and aquaculture. The identification method was used for this study, and the results were analyzed descriptively. The results showed that silkworms from nature positively contained Salmonella sp. and whereas for cultivation results in negative Salmonella sp.

\section{PENDAHULUAN}

Target produksi pembenihan pada ikan air tawar konsumsi dan ikan hias sangat tinggi. Dengan demikian, harus disiapkan pakan terutama pakan alami yang sesuai dengan bukaan mulut larva ikan. Ketersediaan pakan hasil tangkapan di alam sangat rendah, karena cacing sutra hidup di air yang tergenang pada selokan atau parit (Suryadin et al., 2017; Supriyono et al., 2015).

Tubifex sp merupakan pakan yang sangat cocok untuk pertumbuhan ikan. Benih sangat dipengaruhi oleh kualitas pakan dan jenis pakan yang diberikan dapat mempengaruhi kecepatan pertumbuhan, baik bobot maupun panjangnya. Pakan alami yang banyak dimanfaatkan oleh para pembudidaya adalah cacing sutra Tubifex sp. (Chilmawati et al., 2015; Fajri dan Hutabarat, 2014).

Cacing sutra memiliki kandungan gizi yang cukup baik bagi ikan yaitu protein $57 \%$, lemak 13,3\%, serat kasar $2,04 \%$, kadar abu 3,6 \% dan air $(87,7 \%)$ (Prihatini dan Bahrudin, 2016; Bintaryanto dan Taufikurohmah, 2013; Pursetyo et al., 2019; Mandila dan Hidajati, 2013; Nurhidayah, 2018; Wijayanti, 2018).

Untuk memenuhi kebutuhan cacing sutra yang kontinu dilakukan budidaya cacing sutra terkontrol. Keberhasilan budidaya sangat ditentukan oleh nutrisi pada media, pupuk, pakan, dan bahan organik sebagai sumber makanan cacing (Cahyono et al., 2015; Herawati et al., 2016); Suryadin et al., 2017).

Upaya untuk mengoptimalkan produksi cacing sutra yang bebas bakteri Salmonella penting dilakukan karena dapat berbahaya bagi kesehatan manusia dan lingkungan. Berdasarkan hasil uji mikrobiologi, sampel cacing sutra hasil tangkapan dari alam dan kotoran ayam terkontaminasi oleh bakteri Salmonella.

Bakteri Salmonella menyerang sistem pencernaan, sangat dominan pada media yang kadar air dan proteinnya tinggi seperti ikan. Selain itu Salmonella dapat menyebabkan infeksi pada manusia serta penolakan produk perikanan Indonesia (Sartika et al., 2016). Oleh karena itu, produktivitas budidaya perikanan dapat ditingkatkan dengan menerapkan cara pembenihan ikan yang baik (CPIB).

\section{METODOLOGI}

\section{Waktu dan Tempat}

Penelitian ini dilakukan pada bulan Mei - Juli 2019 di Laboratorium Mikrobiologi dan Laboratorium Basah Sekolah Tinggi Perikanan Jakarta.

\section{Materi Penelitian}

Alat yang digunakan meliputi inkubator, oven, autoclave, neraca analitik, laminar flow, tabung reaksi, cawan petri, bunsen, stomacher, erlemeyer, dan jarum ose. Sampel diambil dari hasil tangkapan dan hasil budidaya.

Bahan yang digunakan adalah kotoran ayam, larutan garam fisiologis 0,85\%, media SSA (Salmonella-Shigella Agar), SCA (Simmons' Ctrate Agar), SIM (Suflide Indole Motility), APW (Alkaline Peptone Water), LIA (Lysine Iron Agar), RV (Rappaport-Vassiliadis), HE (Hektoen Enteric) agar, TSI (Triple Sugar Iron) agar, XLD (Xylose Lysine Deoxycholate) agar, BSA (Bovine Serum Albumin), BPW (Buffered Peptone Water), LB (Lactose Broth), Muller-Kauffmann TetrathionateNovobiocin Broth (MKTTn), nutrient agar, 
pereaksi pewarnaan gram, methyl red, glukosa, sukrosa, kertas oksidase, dan akuades.

\section{Rancangan Penelitian}

Sampel cacing sutra berasal dari Sungai Kota Bogor dan hasil budidaya dari Laboratorium Basah Sekolah Tinggi Perikanan. Sampel yang digunakan masing - masing sampel 100 gram dengan 3 ulangan. Sampel dimasukkan ke dalam plastik steril kemudian dibawa ke laboratorium untuk diamati.

\section{Prosedur Kerja}

Isolasi, Seleksi, dan Identifikasi Bakteri Salmonella sp.

Metode kerja dilakukan sesuai metode BSN (2006a; 2006b). 25 gram sampel ditimbang dan dimasukkan ke dalam botol yang berisi $225 \mathrm{ml}$ BPW. Sampel dihomogenkan dengan stomacher selama 1 menit kemudian diinkubasi pada suhu $35^{\circ} \mathrm{C} \pm 1^{\circ} \mathrm{C}$ selama 24 jam.

Selanjutnya $\quad 0,1 \quad \mathrm{ml} \quad \mathrm{BPW}$ dimasukkan ke dalam $10 \mathrm{ml}$ media RV. Proses inkubasi pada media RV dilakukan dalam waterbath bersuhu $42^{\circ} \mathrm{C} \pm 1^{\circ} \mathrm{C}$ selama 24 jam \pm 2 jam mengikuti metode Fatiqin et al. (2019).

\section{Seleksi pada Media Selektif}

Sebanyak 1 ose bakteri dari media RV diinokulasikan pada media XLD dan BSA dengan metode streak plate. Proses inkubasi dilakukan pada suhu $37^{\circ} \mathrm{C}$ selama 24 jam \pm 2 jam. Bakteri yang tumbuh dan diduga Salmonella sp. pada media XLD memiliki ciri-ciri koloni berwarna merah muda dengan atau tanpa titik hitam atau terlihat hampir seluruh koloni hitam. Sedangkan pada media BSA, bakteri terduga Salmonella sp. berwarna ungu.

\section{Jumlah Angka Lempeng Total (ALT) Bakteri}

10 gram sampel dihaluskan dalam plastik steril kemudian dilarutkan dalam $90 \mathrm{ml}$ larutan garam fisiologis 0,85\% dinyatakan sebagai pengenceran $10^{-1}$. Kemudian sampel diambil sebanyak $1 \mathrm{ml}$ menggunakan pipet steril dari pengenceran $10^{-1}$ dan dimasukkan ke dalam tabung reaksi yang berisi $9 \mathrm{ml}$ larutan garam fisiologis $0,85 \%$ untuk mendapatkan pengenceran $10^{-2}$ sampai $10^{-7}$. Tiap-tiap pengenceran diambil $0,1 \mathrm{ml}$ dan dipindahkan pada media Total Plate Count (TPC) kemudian diinkubasi selama 24-48 jam pada suhu $37^{\circ} \mathrm{C}$ dan dihitung jumlah koloni yang tumbuh.

\section{Uji Kualitatif Salmonella sp.}

25 gram sampel kotoran ayam dan cacing sutra yang telah dihaluskan dimasukkan ke dalam erlenmeyer yang berisi $225 \mathrm{ml}$ media LB kemudian dihomogenkan selama 2 menit (pengenceran $10^{1}$ ). Sampel kemudian digoreskan pada media SSA kemudian diinkubasi selama 24 jam pada suhu $37^{\circ} \mathrm{C}$. Koloni terpisah diamati morfologinya (bentuk, diameter, elevasi, tepian, warna, dan konsistensi) dan dilanjutkan dengan morfologi sel dengan pewarnaan Gram (bentuk dan ukuran sel). Koloni yang telah diamati secara mikroskopis ditanam pada nutrient agar untuk uji biokimia (BSN, 2006b).

\section{Uji Biokimia Salmonella sp.}

Hasil isolasi bakteri Salmonella sp. kemudian diuji lanjut dengan uji biokimia meliputi oksidasi, katalase, motility, fakultatif, methyl red, voges proskauer, indol, produksi $\mathrm{H}_{2} \mathrm{~S}, \mathrm{O} / \mathrm{F}$ (oksidasi/ fermentasi), dan glukosa. Kemudian diidentifikasi berdasarkan Bergey's Manual of Determinative Bacteriology.

\section{Analisis Data} deskriptif.

Analisis data dilakukan secara

\section{HASIL DAN PEMBAHASAN}

Isolasi Bakteri Salmonella sp. Pada Cacing Sutra Hasil Tangkapan

Pada isolasi untuk identifikasi, penggoresan dilakukan dari media pengkayaan ke media XLD dan HE sebagai media selektif lalu diinkubasi 
selama 24 jam dengan suhu $37^{\circ} \mathrm{C}$. Pada media HE dan XLD terdapat bintik hitam di tengah koloni. Terlihat zona transparan karena perubahan indikator dalam media koloni hijau kebiruan dengan inti hitam positif Salmonella sp. Pada hasil pengujian media XLD terdapat koloni pink yang menandakan positif bakteri Salmonella pada cacing hasil tangkapan dari alam.
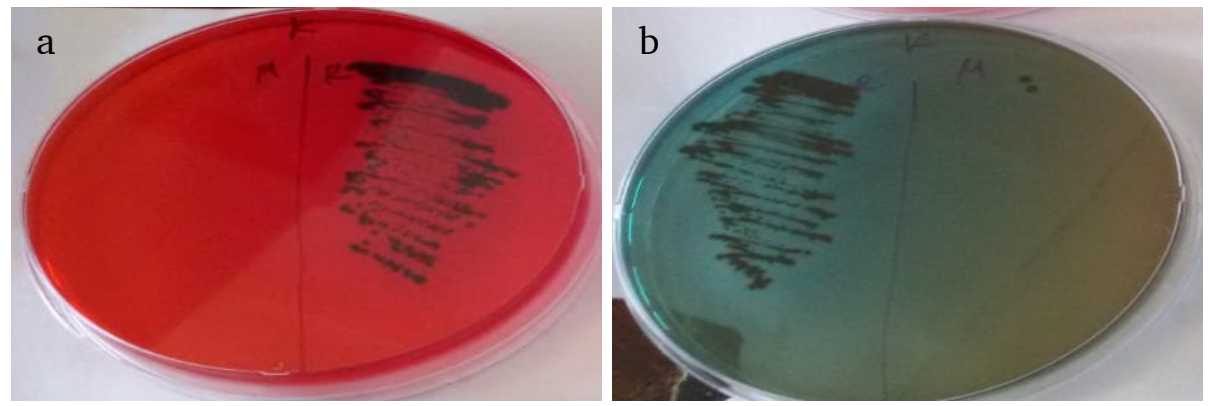

Gambar 1. Biakan Salmonella sp. yang tumbuh pada berbagai media. a : XLD (Xylose Lysine Deoxycholate) agar; b : HE (Hektoen Enteric) agar.

\section{Pengujian Biokimia}

Pada identifikasi selanjutnya digunakan LIA, dengan tusuk ungu pada pengujian, dan TSI + dengan tusukan kuning pada hasil pengujian. Perubahan warna hitam pada pengujian TSI dan LIA, merah menyala pada methyl red, serta biru pada SCA menandakan positif Salmonella sp. Pengujian positif ditemukan dari cacing sutra hasil tangkapan alam positif. Selain itu pertumbuhan ditandai dengan kekeruhan dan bau yang khas (Yuliani et al., 2009).

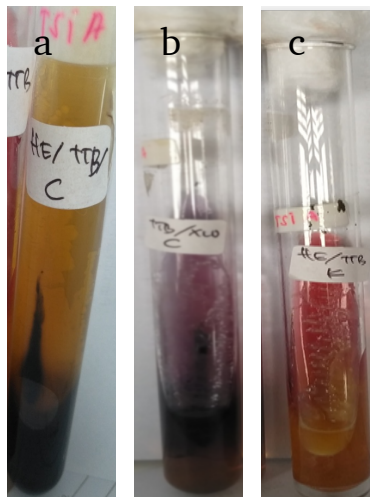

Gambar 2. Pengujian biokimia. a : HE/TTB pada uji biokimia merah menjadi kuning tusuk hitam positif; b : XLD/TTB perubahan merah menjadi ungu terdapat $\mathrm{H}_{2} \mathrm{~S}$ positif; c : HE/TTB TSI merah kekuningan tusuk hitam positif.

Hasil pengujian biokimia seperti TSI A dapat dibagi menjadi 3 bagian, yaitu glukosa, laktosa, dan sukrosa. Pembentukan gas dari fermentasi $\mathrm{H}_{2} \mathrm{~S}$ dan $\mathrm{CO}_{2}$ dapat dilihat dari media agar pada tabung yang terangkat. Pengendapan hitam yang terjadi pada pembentukan $\mathrm{H}_{2} \mathrm{~S}$ positif disebabkan karena bakteri mampu mendesulfurisasi asam amino dan metionin yang dapat menghasilkan $\mathrm{H}_{2} \mathrm{~S}$.
Reaksi Fe dan $\mathrm{H}_{2} \mathrm{~S}$ akan menghasilkan endapan hitam yang disebabkan oleh proses oksidasi asam oleh udara dan pemecahan protein pada media agar miring.

Pertumbuhan Salmonella sp. pada media XLD dan HE ditandai dengan terbentuknya koloni berwarna kehitaman. Pada pengamatan secara mikroskopis, Salmonella memiliki sifat gram negatif 
yang ditandai dengan isolat berwarna merah muda seperti pada Gambar 3.

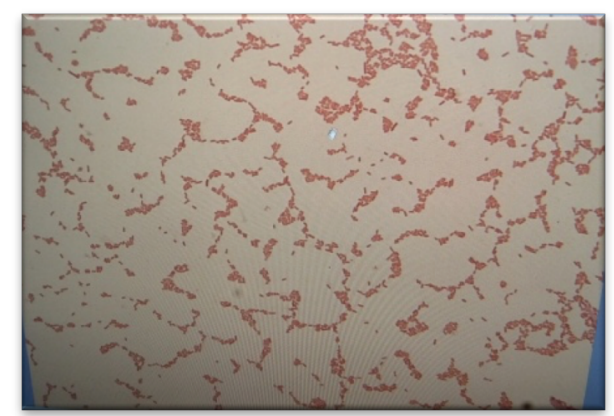

Gambar 3. Mikroskopis Salmonella sp. bakteri gram negatif berwarna merah muda dengan besaran 1000 lux.

Sampel cacing sutra tangkapan dari alam positif terinfeksi bakteri Salmonella. Bakteri ini menyebabkan penyakit enterik yang umum dan tersebar di dunia sebagai penyebab diare akut dan kronis, serta menyebabkan kematian pada manusia tetapi tidak untuk ikan (Yuliani et al., 2009). Cacing sutra yang digunakan pada unit pembenihan sebagai pakan alami untuk larva ikan yang mengandung Salmonella tidak direkomendasikan untuk usaha budidaya.

Tabel 1. Hasil identifikasi biokimia pada cacing sutra tangkapan dari alam yang positif mengandung Salmonella sp.

\begin{tabular}{llc}
\hline \multicolumn{1}{c}{ Pengujian } & \multicolumn{1}{c}{ Hasil } & Salmonella sp. \\
\hline a. Hectoen Enteric (HE) & $\checkmark$ Koloni hijau kebiruan dengan inti & + \\
b. Xylose Lysine Deoxycholate & $\checkmark$ Koloni pink & + \\
$\quad$ (XLD) agar & $\checkmark$ Tusukan kuning & + \\
c. Triple Sugar Iron (TSI) agar & $\checkmark$ Tusukan ungu & + \\
d. Lysine Iron Agar (LIA) & $\checkmark$ Hitam & + \\
e. H2S (TSI dan LIA) & $\checkmark$ Tidak ada perubahan warna & - \\
f. Urease & $\checkmark$ Tidak ada perubahan warna & - \\
g. Uji Voges Proskauer & $\checkmark$ Warna kuning pada permukaan & - \\
h. Uji Indol & $\checkmark$ Warna merah menyebar & + \\
i. Uji Methyl Red & $\checkmark$ Ada pertumbuhan warna biru & + \\
j. Simmons' Citrate &
\end{tabular}

Isolasi Bakteri Salmonella sp. Pada Cacing Sutra Hasil Budidaya

Identifikasi dilakukan pada cacing sutra hasil budidaya yang menggunakan media kotoran ayam, dedak, ampas tahu, dan lumpur dengan sistem sirkulasi air pemeliharaan selama 21 hari dengan perlakuan fermentasi. Bakteri Salmonella sangat cepat berkembang pada kondisi lingkungan yang buruk dan tercemar. Dengan budidaya yang baik dan penanganan yang bersih, bakteri Salmonella akan hilang.

25 gram sampel cacing sutra hasil budidaya dan $250 \mathrm{ml}$ larutan BPW diinkubasi pada suhu $37{ }^{\circ} \mathrm{C}$ dengan perbandingan sampel 1:10 selama 18 jam. Kemudian 0,1 ml sampel dimasukkan ke dalam $10 \mathrm{ml}$ RVS dan diinkubasi selama 24 jam pada suhu $41,5{ }^{\circ} \mathrm{C}$. Selanjutnya 1 $\mathrm{ml}$ sampel dimasukkan ke dalam $10 \mathrm{ml}$ MKTTn dan diinkubasi selama 24 jam pada suhu $37^{\circ} \mathrm{C}$. 


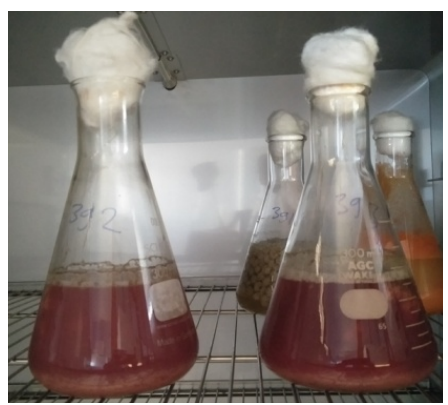

Gambar 4. Sampel cacing sutra hasil budidaya.
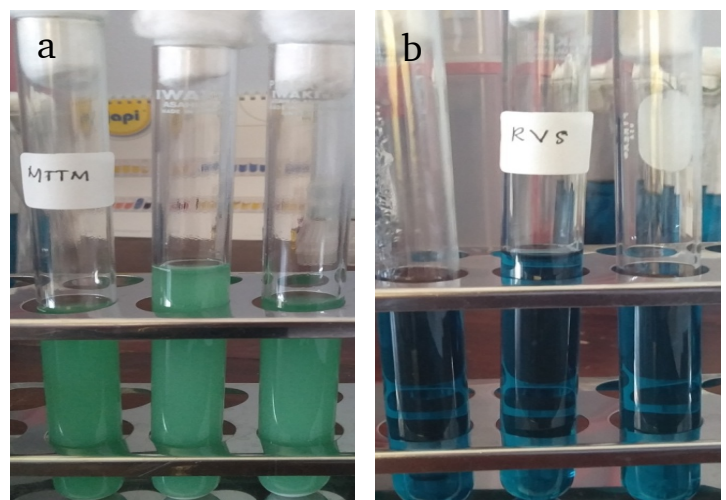

Gambar 5. a : MKTTn warna hijau; b: RVS warna biru.

\section{Preparasi Untuk Identifikasi}

Media XLD dan HE disiapkan, kemudian dilakukan penggoresan dari hasil inkubasi RVS dan MKTTn selama 24 jam dengan suhu $37{ }^{\circ} \mathrm{C}$. Tidak terdapat perubahan dan bintik hitam sehingga disimpulkan bahwa hasil identifikasi koloni Salmonella negatif. Identifikasi tidak dilanjutkan dengan uji biokimia karena sudah dapat disimpulkan bahwa cacing budidaya negatif Salmonella.

Pada HE dan XLD tidak ada perubahan warna dan tidak ada pertumbuhan, dapat dilihat pada Gambar 5 dan Tabel 2 berikut.
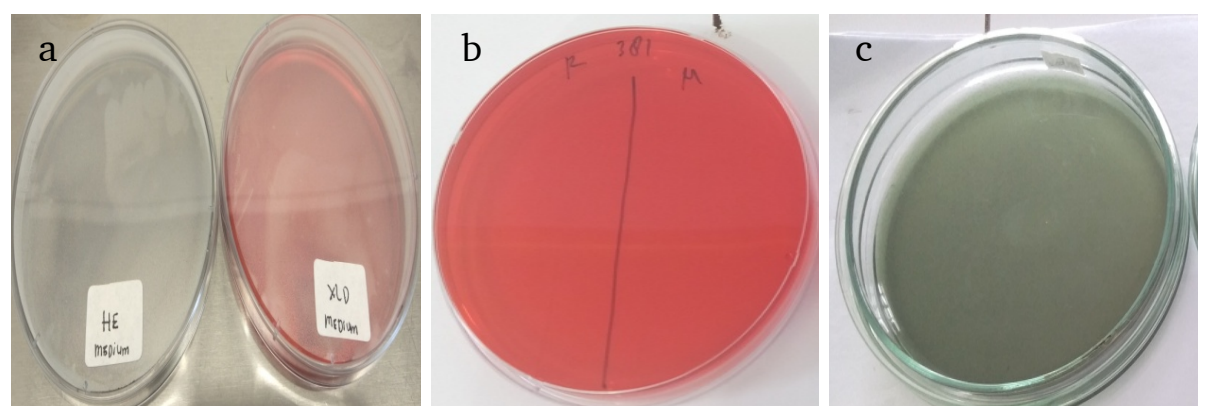

Gambar 6. Preparasi pra-identifikasi dan proses identifikasi. a : media agar HE dan XLD sebelum digores; $\mathrm{b}$ : tidak ada perubahan warna pada media XLD setelah digores dan inkubasi negatif; c : tidak ada perubahan warna pada media HE setelah digores dan inkubasi negatif.

Tabel 2. Hasil identifikasi pada cacing sutra budidaya.

\begin{tabular}{lllc}
\hline \multicolumn{2}{c}{ Pengujian } & \multicolumn{1}{c}{ Hasil } & Salmonella sp. \\
\hline a. Hectoen Enteric (HE) & $\checkmark$ & Tidak ada perubahan warna dan tidak ada \\
& koloni tumbuh & - \\
b. Xylose $\quad$ Lysine & $\checkmark$ & $\begin{array}{l}\text { Tidak ada perubahan warna dan tidak ada } \\
\text { keloni tumbuh }\end{array}$ & - \\
&
\end{tabular}


Hasil penelitian Nurfitriani et al. (2014) pada budidaya cacing sutra dengan pemupukan fermentasi kotoran ayam berpengaruh terhadap populasi dan biomassa cacing serta mengurangi kontaminasi mikroba Salmonella sp. Hasil budidaya cacing dapat dikontrol dari proses awal budidaya hingga panen yang dilakukan secara teliti sehingga dapat di pastikan bahwa cacing yang akan di berikan pada benih ikan adalah cacing yang sehat.

\section{KESIMPULAN}

Berdasarkan hasil penelitian dapat disimpulkan bahwa dari kedua sampel, cacing sutra yang berasal dari tangkapan alam terkontaminasi oleh bakteri gram negatif Salmonella sp. Sedangkan cacing sutra hasil budidaya tidak tercemar oleh bakteri Salmonella sp. Pembudidaya sebaiknya memberikan cacing hasil budidaya pada benih ikan dengan rekomendasi sistem fermentasi pupuk hewani atau bahan organik lainnya sehingga dapat dipastikan cacing bebas Salmonella sp.

\section{UCAPAN TERIMAKASIH}

Kami mengucapkan terima kasih kepada Sekolah Tinggi Perikanan Jakarta dan semua pihak yang membantu dalam penyelesaian penelitian ini.

\section{DAFTAR PUSTAKA}

Badan Standarisasi Nasional. 2006a. SNI 01-2332.1-2006, Cara Uji Mikrobiologi - Bagian1: Penentuan Coliform dan Eschericia coli pada Produk Perikanan. Jakarta: Badan Standarisasi Nasional. $21 \mathrm{hlm}$.

Badan Standarisasi Nasional. 2006b. SNI 01-2332.2-2006, Cara Uji Mikrobiologi - Bagian 2: Penentuan Salmonella pada Produk Perikanan. Jakarta: Badan Standarisasi Nasional. 29 hlm.

Bintaryanto, B.W. dan Taufikurohmah, T., 2013. Pemanfaatan Campuran Limbah Padat (Sludge) Pabrik Kertas dan Kompos sebagai Media
Budidaya Cacing Sutra (Tubifex. sp). UNESA Journal of Chemistry, 2(1), $\quad$ pp.1-7. https:// jurnalmahasiswa.unesa.ac.id/index. php/unesa-journal-of-chemistry/ article/download/1256/914

Cahyono, E.W., Hutabarat, J. dan Herawati, V.E., 2015. Pengaruh pemberian fermentasi kotoran burung puyuh yang berbeda dalam media kultur terhadap kandungan nutrisi dan produksi biomassa cacing sutra (Tubifex sp.). Journal of Aquaculture Management and Technology, 4(4), pp.127-135. https://ejournal3.undip.ac.id/index .php/jamt/article/download/10071 19778

Chilmawati, D., Suminto, S. dan Yuniarti, T., 2015. Pemanfaatan Fermentasi Limbah Organik Ampas Tahu, Bekatul dan Kotoran Ayam Untuk Peningkatan Produksi dan Kualitas Kultur Cacing Sutera (Tubifex sp). PENA, 28(2), pp.186-201. http:// eprints.undip.ac.id/51060/2/Artike 1_PENA\%2C_Maret_2015.pdf

Fajri, W.N. dan Hutabarat, J., 2014. Pengaruh Penambahan Kotoran Ayam, Ampas Tahu Dan Tepung Tapioka Dalam Media Kultur Terhadap Biomassa, Populasi dan Kandungan Nutrisi Cacing Sutera (Tubifex sp.). Journal of Aquaculture Management and Technology, 3(4), pp.101-108. https://ejournal3. undip.ac.id/index.php/jamt/article /view/6646/6414

Fatiqin, A., Novita, R. dan Apriani, I., 2019. Pengujian Salmonella Dengan Menggunakan Media SSA dan E. Coli Menggunakan Media EMBA Pada Bahan Pangan. Indobiosains, 1(1),pp.22-29. https://jurnal. univpgri-palembang.ac.id/index. php/biosains/article/viewFile/2206 $/ 2105$

Herawati, V.E, Nugroho, R.A., Darmanto, Y.S. dan Hutabarat, J., 2016. Analisis Pemberian Pakan Tubifex Sp. Hasil Kultur Massal Menggunakan Fermentasi Kotoran 
Ayam, Roti Afkir dan Ampas Tahu Terhadap Performa Pertumbuhan Dan Kelulushidupan Larva Lele (Clarias gariepenus). Prosiding Seminar Nasional Tahunan Ke-V 2015 Hasil-Hasil Penelitian Perikanan dan Kelautan. Fakultas Perikanan dan Ilmu Kelautan UNDIP, pp. 188-198. http://eprints. undip.ac.id/51066/1/B2_02(22).pd $\mathrm{f}$

Mandila, S.P. dan Hidajati, N., 2013. Identifikasi Asam Amino Pada Cacing Sutra (Tubifek sp.) yang Diekstrak dengan Pelarut asam Asetat dan Asam Laktat. UNESA Journal of Chemistry. UNESA Journal of Chemistry, 2(1), pp.103108. https://jurnalmahasiswa. unesa.ac.id/index.php/unesajournal-of-chemistry/article/view/ $1155 / 848$

Nurfitriani, L., Suminto dan Hutabarat, J., 2014. Pengaruh penambahan kotoran ayam, ampas tahu dan silase ikan rucah dalam media kultur terhadap biomassa, populasi dan kandungan nutrisi cacing sutera (Tubifex sp.). Journal of Aquaculture Management and Technology, 3(4), pp.109-117. https://ejournal3. undip.ac.id/index.php/jamt/article /view/6647/6443

Nurhidayah, W., 2018. Pengaruh Perbedaan Konsentrasi dan Jenis Pupuk Organik Cair Terhadap Biomassa Mutlak Cacing Sutra (Tubifek Sp) Dalam Sistem Resirkulasi. Jurnl Prodi Biologi, 7(4), pp.246-254. http://journal.student. uny.ac.id/ojs/index.php/biologi/art icle/download/12759/12294

Prihatini, E.S. dan Bahrudin, B., 2016. Pemanfaatan Cacing Sutra Tubifex sp Untuk Kelangsungan Hidup Benih Ikan Lele Sangkuriang Clarias gariepinus var sangkuriang. Grouper, 7(1), pp.5-9. https://doi. org/10.30736/grouper.v7i1.43

Pursetyo, K.T., Satyantini, W.H. dan Mubarak, A.S., 2011. Pengaruh Pemupukan Ulang Kotoran Ayam
Kering Terhadap Populasi Cacing Tubifex tubifex [The Effect Of Remanuring Dry Chicken Manure In Tubifex tubifex Population]. Jurnal Ilmiah Perikanan dan Kelautan, 3(2), pp.177-182. https://doi.org/ 10.20473/jipk.v3i2.11604

Sartika, D., Susilawati, S. dan Anjung, M.U.K., 2016. Kajian Cemaran Salmonella sp. pada Pasca Panen Udang Vannamei Hasil Budidaya di Wonosobo, Kota Agung, Hanura dan Rawajitu Timur. Inovasi Pembangunan: Jurnal Kelitbangan, 4(03), pp.244-252. http:// repository.lppm.unila.ac.id/1891/1 /JURNAL\%20DEWI\%20SARTIKA.p df

Supriyono, E., Pardiansyah, D., Putri, D.S. dan Djokosetianto, D., 2015. Perbandingan jumlah bak budidaya cacing sutra (tubificidae) dengan memanfaatkan limbah budidaya ikan lele (clarias sp) sistem intensif terhadap kualitas air ikan lele dan produksi cacing sutra. DEPIK Jurnal Ilmu-Ilmu Perairan, Pesisir dan Perikanan, 4(1). https://doi.org/10. 13170/depik.1.1.2279

Suryadin, D., Helmiati, S. dan Rustadi, R., 2017. The Effect of Thickness of Medium for Silkworm (Tubifex sp.) Culture using Waste Sludge of Catfish Cultivation. Jurnal Perikanan Universitas Gadjah Mada, 19(2), pp.97-105. https://doi.org/ 10.22146/jfs.26015

Wijayanti, D., 2018. Pengaruh Presentase Pemberian Pakan Alami Cacing Sutra (Tubifex Sp) Dan Pakan Buatan Terhadap Frekuensi Moulting Dan Pertumbuhan Udang Galah (Macrobrachium rosenbergii) STADIA V (PhD Thesis). University of Muhammadiyah Malang. http:// eprints.umm.ac.id/id/eprint/43779

Yuliani, N.S., Wera, E. dan Bulu, P.M., 2009. Identifikasi bakteri Salmonella sp dan jumlah total kontaminan bakteri Coliform pada ikan kembung (Scomber sp) yang dijual di pasar Inpres dan Oeba. 
Partner, 16(1), pp.16-20. http:// jurnal.politanikoe.ac.id/index.php/j $\mathrm{p} /$ article/view/49/46 